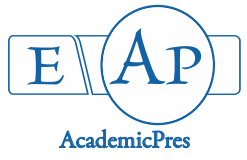

Roman AM et al. (2020)

Notulae Scientia Biologicae 12(4):940-958

DOI: $10.15835 / 12410867$

Research Article

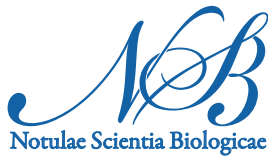

\title{
Trees, seeds and seedlings analyses in the process of obtaining a quality planting material for black locust (Robinia pseudoacacia L.)
}

\author{
Andrea M. ROMAN ${ }^{1,2}$, Irina M. MORAR ${ }^{2 *}$, Alina M. TRUTA2, \\ Cătălina DAN ${ }^{2}$, Adriana F. SESTRAS ${ }^{2}$, Liviu HOLONEC ${ }^{2}$, \\ Florin IORAS ${ }^{3 *}$, Radu E. SESTRAS ${ }^{2}$ \\ ${ }^{1}$ Forestry College Transilvania, Năsăud, Romania; andreearoman34@gmail.com \\ ${ }^{2}$ University of Agricultural Sciences and Veterinary Medicine, Faculty of Horticulture, 3-5 Mănăștur Street, 400372 Cluj-Napoca, \\ Romania;irina.todea@usamvcluj.ro (*correspondingauthor); alina_vilcan@yahoo.com; catalina.dan@usamvcluj.ro; \\ adriana.sestras@usamvcluj.ro; Iholonec@usamvcluj.ro; rsestras@usamvcluj.ro \\ ${ }^{3}$ Buckinghamshire New University, Queen Alexandra Road, High Wycombe, HP11 2JZ Buckinghamshire, \\ England; florin.ioras@bucks.ac.uk (*corresponding author)
}

\begin{abstract}
Black locust (Robinia pseudoacacia L.) was among the first North-American tree species imported in Europe. In Romania, black locust has established itself as a forest tree appreciated for multiple uses. The objective of the hereby study was to identify a quality planting material at black locust using seeds from trees with superior traits from five stands geographically close, located in North-western of Romania. An empirical selection was done, thus trees with the most favourable traits were selected as plus trees. Among the averages of the main traits (tree height, diameter at breast height, basal area, self pruning trunk length, crown diameter) of the plus trees from the five stands, there were registered significant differences, and two stands stood out with a high biomass growth. Even if the stands had different ages (between 20-35 year), the age did not influence significantly the growth traits of the trees. The seeds of the plus trees (open-pollinated) from all the stands had large size (mean seed weight of $0.057 \mathrm{~g} / \mathrm{seed}$ ). The seedling emergence rate was high, especially in the solarium condition (between $52.7-73.7 \%$ compared with $33.0-41.3 \%$ in the field). Coefficient of genetic correlation and heritability calculated for the seedlings belongings to half-sib families highlighted that black locust breeding can be extremely effective by a proper selection.
\end{abstract}

Keywords: biomass growth; emergence rate; heritability; quality wood; plus trees; seeds

\section{Introduction}

Black locust (Robinia pseudoacacia L.) is native to the eastern part of North America, especially the Appalachian regions (Little, 1971; Huntley, 1990). First introduced in Europe, in France and England around 1600, black locust has become increasingly important throughout Europe and some parts of Asia (Keresztesi, 1988a). It is grown in temperate and subtropical regions in the U.S.A., Europe, New Zealand, India, China, 
and Korea. Thus, by the early 17 th century, black locust had been introduced to Europe (Ernyey, 1927; Kolbek et al., 2004). Nowadays, black locust appears in many European countries, especially in Northern Germany, Hungary, Czech Republic, Western Poland, Southern Slovakia, and Eastern Austria, including Romania (Vítková et al., 2017; Carl et al., 2019).

R. pseudoacacia has been studied for a long period of time in Central Europe (Keresztesi, 1988; Kowarik, 1992; Cierjacks et al., 2013), especially because of its economic value rather than its ecology (Min-Sheng et al., 2004; Lukasiewicz et al., 2015; Quinkenstein and Jochheim, 2016).

The fruit is a pod of 5-10 cm long and 1-2 cm wide, flattened, dehiscent, with 4-10(15) kidney-shaped seeds, brown or black, 3-8 mm long, with very hard and impermeable tegument (Farrar, 1995; Șofletea and Curtu, 2007). Brown seeds are larger and germinate faster after sowing compared with black seeds, which are smaller and have a stronger seed coat and heavier germination (Rubțov, 1961). In general, seed propagation is the easiest and most advantageous method of growing, but without previous treatments, seed germination may be low due to the physiological dormancy induced by the impermeable tegument covering the seeds (Liu et al., 1981; Singh et al., 1991; Rédei et al., 2012). In forestry, various chemical and mechanical treatments are used to improve the germination rate. The germination capacity of black locust seeds is facilitated by submersion in boiling water, as a mechanical treatment (scarification), or by a chemical treatment (using diluted sulphur acid) before sowing (Negulescu and Săvulescu 1957; Haralamb, 1967; Costea et al., 1969; Damian, 1978; Keresztesi 1980, Nicolescu et al., 2018). Kolbek et al. (2004), Masaka and Yamada (2009) obtained results with high germination rates by immersing the seeds in boiled water at temperatures of $60-80^{\circ} \mathrm{C}$, soaking time $(20 \mathrm{~min}$ to $72 \mathrm{~h}$ ) and the number of heating water cycles/cooling (1-7). In addition to this method of scalding, in practice, it may also be sufficient using a chemical method, by immersing the seeds for $60 \mathrm{~min}$ in concentrated sulfuric acid, then washing the seeds in cold water and then leaving them to dry at adjusted temperature (Bonner and Karrfalt, 2008). Another successful method is by scarifying the seeds: dried seeds are taken and placed in a metal container with gravel, or by manual abrasion using sandpaper (Bouteiller et al., 2017). The container is energetically agitated so that the seed coat is scratched (Usberti and Martines, 2007).

Black locust is an important woody species, introduced in Romania around 1750, imposing itself as a forest tree, but much appreciated for multiple other uses (Nicolescu et al., 2018). The first reference about the studied species was in 1875 by the economist P. S. Aurelian in the publication "Tiara nostra" (Drăcea, 2008; Ciuvăț et al., 2013) and the first black locust plantation was established in 1852 in the South-West of Romania (Stanescu, 1979; Nicolescu et al., 2018). Today it is widespread and is a valued species, having multiple uses and exploitations. Black locust has a rapid growth since the first years of life, it is distinguished by the ease of cultivation and the value of wood, with multiple uses (Drăcea, 2008). The rusticity of the species, respectively the ecological plasticity were other factors that determined the spread and wide use outside its natural area. $R$. pseudoacacia it is a nitrogen-fixing pioneer species (Carl et al., 2019), often found on abandoned fields and dry slopes (Cierjacks et al., 2013), and is reported as growing well on acid, dry and infertile sandy soils.

$R$. pseudoacacia is widely planted also for revegetation and to control soil erosion, since 1950s (Guo et al., 2005; Tateno et al., 2007). It was used as a pioneer tree species due to its fast growth and strong capacity in improving soil nitrogen content and nutrients' availability, available phosphorus pool, organic carbon sequestration, as well as enhancing soil chemical and microbiological properties (Gillespie and Pope, 1990; Olesniewicz and Thomas, 1999; Rice et al., 2004; Ussiri et al., 2006; Qiu et al., 2010; Wang et al., 2012; Zhang et al., 2016). Even more, the choice of $R$. pseudoacacia in soil erosion control on Loess Plateau, which is one of the most severely eroded areas in the world due to frequent heavy summer rain storms, steep landscapes, longterm human activities (since the 15th century) and highly erodible soils (An et al., 2010), was also because of its important economic value: it produces durable and rot-resistant wood, as well as honey (Dalby, 2004); it can be used in coppice system and as fodder in silvopastoral systems (Cierjacks et al., 2013); it has the potential for bio-oil production and fuel ethanol derived from biomass (Grünewald et al., 2009; Balat, 2010; GonzálezGarcía et al., 2011). 
In Europe, some areas lack highly productive native species with wood or growth characteristics suitable for plantation forestry, thus specialists need to focus largely on exotic species such as black locust as it can be easily established on certain sites, the species has better growth rates than native species and possesses wider physiological adaptability in terms of site conditions. Therefore, $R$. pseudoacacia has been used many times for various purposes such as timber or firewood, re-vegetation of dry land, soil stabilization, as a source of nectar for honey and ornamental purposes (Keresztesi, 1988; Redei et al., 2008; Nicolescu et al., 2018). $R$. pseudoacacia wood is durable, dense, with household and industrial uses, especially as parquet or even furniture, and is an excellent fuel. The species has a relatively high resistance to adversity, in the ecological conditions of Romania, sometimes suffering from late frosts.

In Romania, although fossil fragments of this species were found in rock layers corresponding to the Tertiary geologic period in Europe, black locust is considered as non-native species, the origin of the first individuals being still debatable. The area occupied by black locust trees in Romania has increased continuously, being approximately 250,000 ha (Giurgiu, 2005; Șofletea and Curtu 2007; Nețoiu, 2012; Ciuvăț et al., 2013). $R$. pseudoacacia is considered to be a fast-growing species as mentioned, whereas in the first season (in the case of sprouts) it can reach heights of $6 \mathrm{~m}$ and get to heights of $30 \mathrm{~m}$ at the age of 30-35 years, with basal diameters of $30 \mathrm{~cm}$ at 15 years (Drăcea, 2008; Ciuvăț et al., 2013), depending on the type of regeneration and site conditions. Several black locust populations cultivated in Romania fall into the category of "fast growing", achieving average increases of $15-17 \mathrm{~m}^{3} /$ year/ha and reach the age of absolute exploitability at 30 years (Ciuvăt et al., 2013).

Black locust is a heliophilous species with little shade-tolerance, but slightly tolerates lateral shading, old stands being loose with not much influence on internal climate (Șofletea and Curtu, 2007). The species grows well in warm regions with long summers, on the sands / sandy soils like the northwest, southern and eastern parts of Romania and it is rarely found in cold regions as mountains because of the exposure to early frost (which affects the young shoots) and very cold and long winters (Nicolescu et al., 2020). Being a thermophile species, the best site conditions for black locust stands in Romania are in the South of the country, in Oltenia geographical region, as reflected by the research made by Ivanschi et al. (1969) in order to establish the most suitable sites for the cultivation of black locust.

$R$. pseudoacacia is also important for carbon sequestration, soil stabilization and re-vegetation of landfills, mining areas and wastelands, in biotherapy and landscaping. In Europe, black locust is drought tolerant so it grows in areas with annual precipitation as low as $500-550 \mathrm{~mm}$. It tolerates dry, nutrient poor soils, but grows best on deep, nutrient-rich, well-drained soils. The species is regarded as invasive in several European countries and its range is expected to expand under predicted climate changes (Enescu and Dănescu, 2013; Nicolescu et al., 2020).

It seems that the current trend is to restrict the cultivation surfaces in areas with high productive potentials, as they are increasingly used for agricultural crops in irrigated systems. In the area of origin in North America, compared to large coniferous or even deciduous species, $R$. pseudoacacia has only a low economic value. However, it is attributed an important role in fixing nitrogen through the roots (Boring and Swank, 1984; Xu et al., 2019). Therefore, it is considered to be a good associate or precursor of other deciduous trees. However, the extension is largely dependent on the extent of the attack of locust borer (Megacyllene robiniae), which damages the wood and makes it unfit for commercial use (DeGomez and Wagner, 2001). The special rusticity of $R$. pseudoacacia gives it, in the forestry policy of many countries, an important place in the afforestation projects in extreme resorts or altered by the anthropic factor. Nicolescu et al. (2018) considered that $R$. pseudoacacia has a special history associated with each country, whereas it was introduced and cultivated as an exotic species.

Due to the presented considerations, it goes without saying that black locust breeding works are perfectly justified, with the aim to increase productivity (by obtaining genotypes with rapid growth rate and capacity to accumulate wood mass), wood quality, production of secondary products (i.e. nectar), resistance to unfavourable environmental conditions, resistant to the attack of diseases and pests, adaptability, as well as 
obtaining forms with the special value from a decorative point of view, the capacity to capitalize and improve degraded lands, etc.

The purpose of the present study was to identify a quality planting material of black locust using seeds from $R$. pseudoacacia trees with superior characteristics selected from five stands geographically close, located in North-western of Romania.

\section{Materials and Methods}

\section{Study site}

The selection of black locust (R.pseudoacacia) trees with superior characteristics from which seeds were harvested was made from five sites represented by forest plantations from forest district O.S. Jibou, Sălaj County, Romania, which belongs to the National Forest Administration (ROMSILVA).

The area is situated in the North-Western part of Romania and is characterized by a temperate continental climate, the average annual temperature being around $8.2^{\circ} \mathrm{C}$ and the multiannual average of the amount of annual rainfall of about $630 \mathrm{~mm}$. The stands of $R$. pseudoacacia are placed in five localities (Sâmpetru-Almaşului, Voivodeni, Trestia, Chendrea and Gălpâia, in an area of approximately 2,950 ha), within the longest distance is of $16.7 \mathrm{~km}$ between Gălpâia and Voivodeni respectively.

\section{Biological material}

An empirical selection was done from the five zones, delimiting thus five stands, where were identified trees with the most favourable traits (biomass storage capacity, vigorous growth, quality wood - straight and cylindric trunk, respectively rectilinear stem, without defects, with a properly natural pruning, small crown located in the superior part of the tree, main branches inclined at large angles - close to 90 degrees, first quality class of the wood - with the working wood portion with over $50 \%$ of the tree height, very good health condition, grown in good vegetation condition, etc.). The selected trees were thus considered 'plus' trees (five plus trees were chosen from each stand, from each of the five zones).

The stands from which plus trees were selected were of 20-35 years old, whereas the data about the origin of seeds or plants used for the establishment of these stands was not available.

\section{Experimental procedures}

Several measurements of the main growth elements were performed for the selected plus trees (to five of the best trees per stand), i.e.: trees height; diameter at breast height - DBH; basal area or the cross-sectional area of trees at breast height; self-pruning (natural) trunk length; crown diameter based on the large crown diameter and the small crown diameter (maximum and minimum, respectively), which were finally computed as average crown diameter (Figure 1).

Seeds formed under conditions of natural pollination were harvested from the selected trees, individually. The seeds were post-matured in the field by stratification in sand over the winter and sown in the spring (beginning of April), after being previously analysed for the main characteristics (length, width, thickness, volume, weight).

The percentage of seeds' emergence and the main elements of seedlings' growth were analysed separately, for seeds sown in two different conditions: solarium and in the field (Figure 2). In the solarium, the seeds were sown in plastic pots of $200 \mathrm{ml}$ volume, using a soil mix of garden soil (40\%), peat moss (40\%), perlite (10\%) and compost (10\%). Outside, the sowing was done directly in the field, in the close proximity of the solarium, in a soil characteristic for the area of the analyzed stands (brown soil, mull humus, middle texture, moderateacid $\mathrm{pH}$ ), well prepared and loose. The elements of seedlings' growth were analyzed one month after the plants' emergence and at the end of the vegetation period (first decade of October). 


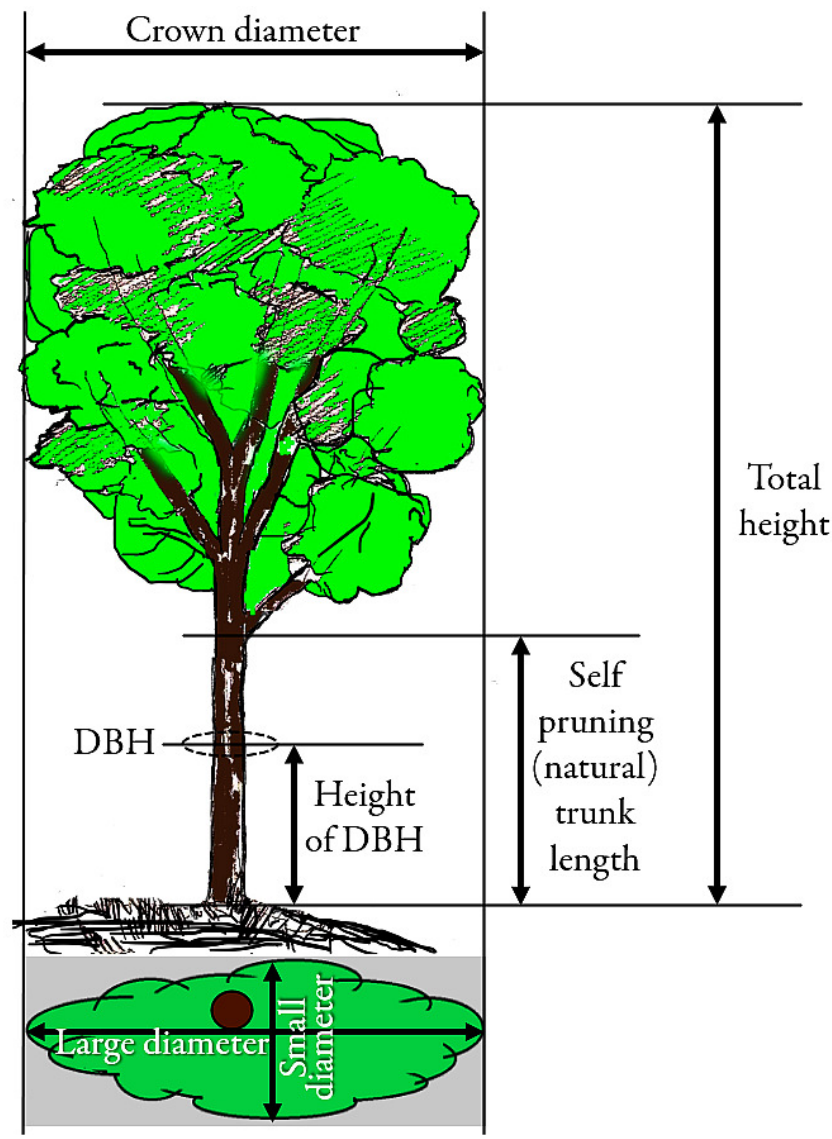

Figure 1. The main growth traits measured at the trees chosen as 'plus' trees. At the bottom of the figure is the projection of the crown at ground level, determined by maximum and minimum diameter
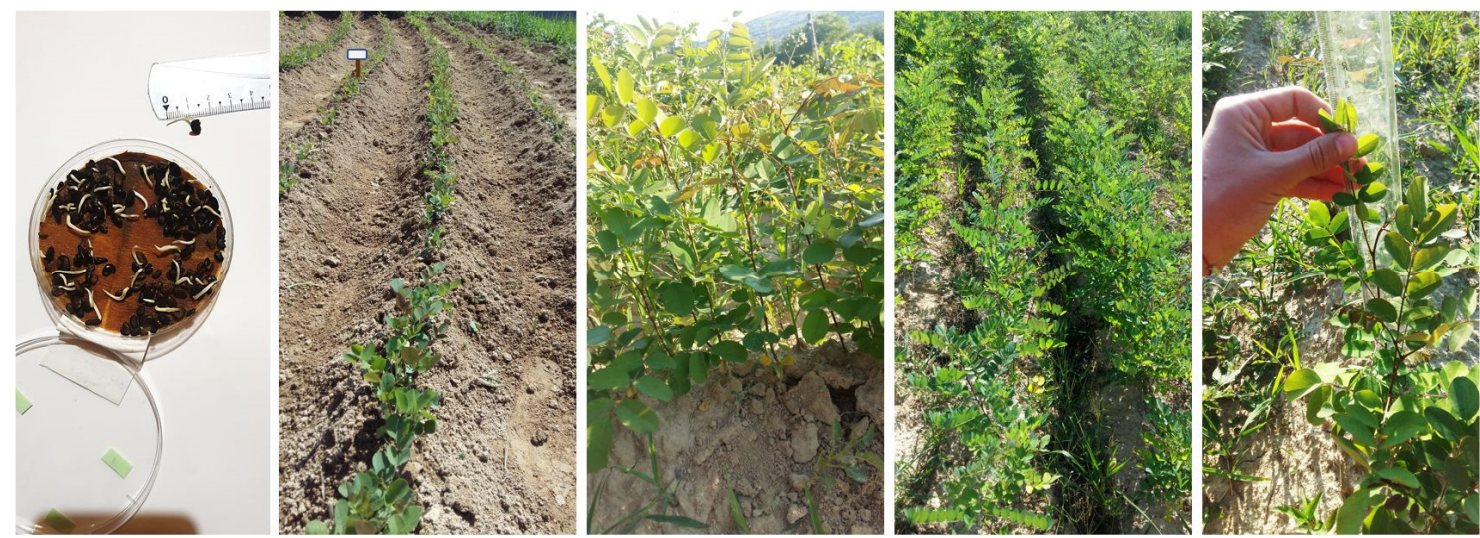

Figure 2. Aspects from the work stages and obtaining black locust seedlings in the field

\section{Statistical analyses}

Data analysed for the traits of the plus trees, seeds and seedlings were statistically processed using Oneway analysis of variance (ANOVA) at alpha $\alpha=0.05$. If statistically significant differences between the means were recorded, Tukey's honestly significant difference $(\alpha=0.05)$ was applied as a posthoc comparison test. To compare seedlings emergence and their traits under the conditions of two different culture (solar and field), 
the T-test for two-samples assuming equal variances $(\alpha=0.05)$ was applied. Data regarding the analysis of the seedlings obtained from the seeds of the plus trees was performed by ANOVA, respectively Tukey HSD as posthoc and the results were presented graphically by mean \pm SE.

The heritability of the seedlings' traits grown in the field (noted at the end of the first year of vegetation) was calculated by the decomposition of the variances within the half-sib (HS) families (Jayaraman, 2000; Bos and Caligari, 2007). The HS-families were considered in the random sample taken from the whole set of HSfamilies, using the means of a randomized complete block design involving two blocks, each consisting of five plots of 100 random seedlings.

\section{Results}

\section{R. pseudoacacia plus trees}

The results regarding the main traits of plus trees selected from the five stands are presented in Table 1 .

Table 1. The main elements of growth and accumulation of biomass of the $R$. pseudoacacia trees

\begin{tabular}{|l|c|c|c|c|c|c|}
\hline \multicolumn{1}{|c|}{$\begin{array}{c}\text { Forest } \\
\text { stand }\end{array}$} & $\begin{array}{c}\text { Tree } \\
\text { height } \\
(\mathrm{m})\end{array}$ & $\begin{array}{c}\text { Diameter at } \\
\text { breast height } \\
\text { DBH }(\mathrm{cm})\end{array}$ & $\begin{array}{c}\text { Basal } \\
\text { area } \\
\left(\mathrm{cm}^{2}\right)\end{array}$ & $\begin{array}{c}\text { Self-pruning } \\
\text { trunk length } \\
(\mathrm{m})\end{array}$ & $\begin{array}{c}\text { Large crown } \\
\text { diameter } \\
(\mathrm{m})\end{array}$ & $\begin{array}{c}\text { Small crown } \\
\text { diameter } \\
(\mathrm{m})\end{array}$ \\
\hline Sâmpetru-Alm. & $15.0^{\mathrm{a}}$ & $21.0^{\mathrm{b}}$ & $350.1^{\mathrm{b}}$ & $9.7^{\mathrm{a}}$ & $3.7^{\mathrm{a}}$ & $2.8^{\mathrm{bc}}$ \\
\hline Voivodeni & $16.1^{\mathrm{a}}$ & $22.5^{\mathrm{a}}$ & $399.6^{\mathrm{a}}$ & $10.4^{\mathrm{a}}$ & $3.2^{\mathrm{b}}$ & $2.6^{\mathrm{c}}$ \\
\hline Trestia & $13.8^{\mathrm{b}}$ & $19.5^{\mathrm{b}}$ & $300.7^{\mathrm{c}}$ & $8.0^{\mathrm{b}}$ & $3.6^{\mathrm{a}}$ & $3.1^{\mathrm{a}}$ \\
\hline Chendrea & $13.6^{\mathrm{b}}$ & $18.4^{\mathrm{bc}}$ & $267.5^{\mathrm{d}}$ & $8.2^{\mathrm{b}}$ & $2.5^{\mathrm{c}}$ & $2.2^{\mathrm{d}}$ \\
\hline Gălpâia & $14.1^{\mathrm{b}}$ & $17.2^{\mathrm{c}}$ & $233.0^{\mathrm{e}}$ & $8.2^{\mathrm{b}}$ & $2.6^{\mathrm{c}}$ & $2.3^{\mathrm{d}}$ \\
\hline Mean & 14.5 & 19.7 & 310.2 & 8.9 & 3.1 & 2.6 \\
\hline
\end{tabular}

Different letters between stands denote significant differences (Duncan test, $\mathrm{p}<0.05$ ).

The plus trees with the highest vigour were those from the Voivodeni stand, with superior values for three important growth characteristics: the height of the trees, the diameter of the trunk, as well as for the basal area or the area of the cross-section of the trunk and self-pruning trunk length. Trees from this stand had the advantage of a longer self-pruning trunk length $(10.4 \mathrm{~m})$ compared to other stands (only Sâmpetru-Almaşului stand was registered with a close value and did not differ significantly for this trait). The plus trees with the lowest vigour were reordered in Gălpaiia, with inferior values compared to the other stands for the trunk diameter, the surface of the trunk cross-section, the large and the small diameter of the crown. Relatively low biomass accumulations also showed the Chendrea plus trees, for at least three elements of growth. It is very likely that a lower capacity for wood accumulation will also be present within the selected trees from Trestia, where the lower value of the trunk length can also illustrate a lower quality of the wood.

On the ensemble of stands, the selected trees presented the lowest coefficient of variability for trees' height $(\mathrm{CV} \%=10.7)$ and $\mathrm{DBH}(\mathrm{CV} \%=12.9 \%)$, respectively the highest one for the basal area of the trees $(\mathrm{CV} \%=25.9)$ (Figure 3).

Between the elements investigated for the plus trees growing from the five stands, there were only positive correlations (Table 2), some of them being statistically assured, with different levels of significance. Thus, the height of the trees was closely correlated with the length of the natural self-pruning trunk $(r=$ $0.977^{* *}$ ). The diameter of the trunk was closely correlated with the basal area of the trunk (as expected, because the basal area was an element calculated on the basis of DBH) and the length of the self-pruning trunk, while the basal area was correlated with the self-pruning trunk length. The large crown diameter was closely correlated with the small crown diameter of the trees. 


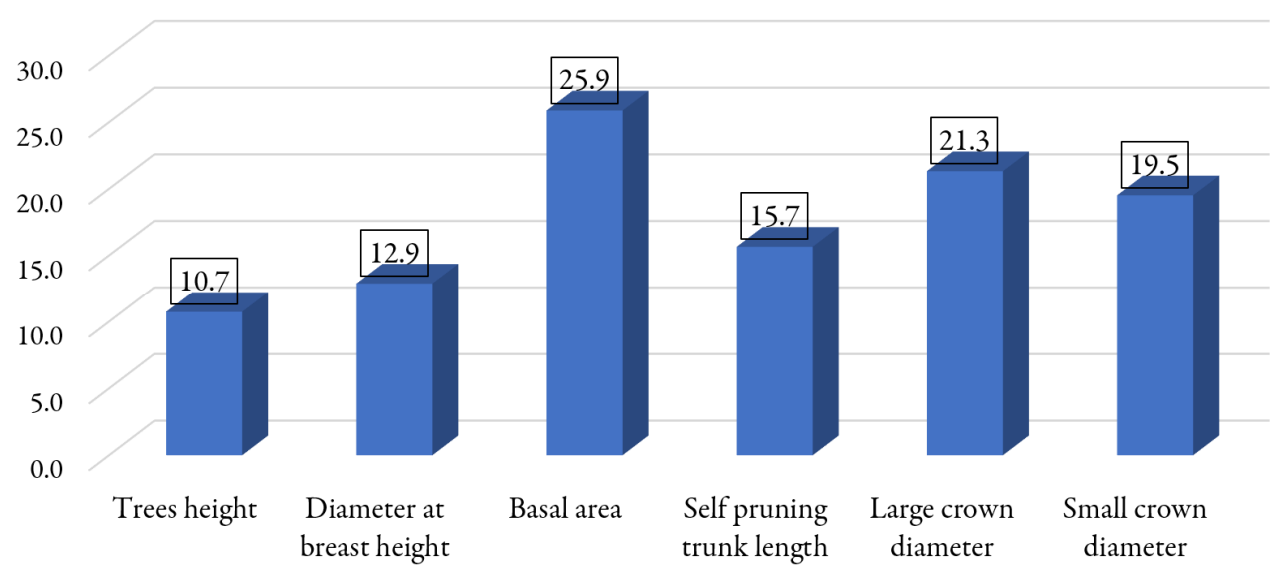

Figure 3. Coefficient of variability (CV\%) for the main growth elements of $R$. pseudoacacia plus trees selected from the five stands

Table 2. Phenotypic correlations between the analysed characteristics of $R$. pseudoacacia plus trees selected from the five stands

\begin{tabular}{|l|c|c|c|c|c|}
\hline \multicolumn{1}{|c|}{ Correlated characteristics } & DBH & Basal area & $\begin{array}{c}\text { Self-pruning } \\
\text { trunk length }\end{array}$ & $\begin{array}{c}\text { Large crown } \\
\text { diameter }\end{array}$ & $\begin{array}{c}\text { Small crown } \\
\text { diameter }\end{array}$ \\
\hline Trees height & 0.854 & 0.870 & $0.977^{* *}$ & 0.346 & 0.155 \\
\hline Diameter at breast height $(\mathrm{DBH})$ & & $0.999^{* * *}$ & $0.879^{*}$ & 0.631 & 0.479 \\
\hline Basal area & & & $0.892^{*}$ & 0.618 & 0.462 \\
\hline Self-pruning trunk length & & & & 0.368 & 0.128 \\
\hline Large crown diameter & & & & & $0.939^{*}$ \\
\hline
\end{tabular}

r $5 \%=0.878 ;$ r $1 \%=0.959 ;$ r $0.1 \%=0.991$.

Because the stands, and consequently selected plus trees, were of different ages, one of the aims of the investigation was to estimate how age influences some important characteristics of trees vigour and wood quality. It is interesting to note that these correlations were not statistically assured. The closest relation was recorded between the age of the trees and the diameter at breast height DBH, but this was not significant (Figure 4). The next growth elements of the trees that had higher values of the correlation coefficient with the age of the trees (but also not statistically assured) were the area of the basal area of the trunk and the large diameter of the crown.

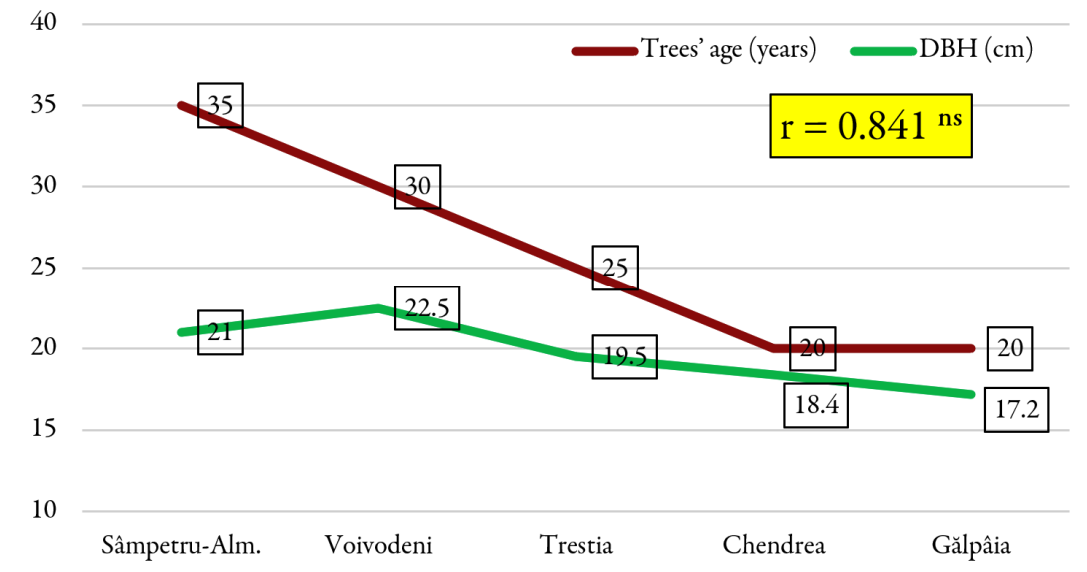

Figure 4. Coefficient of correlation between trees' age (years) and diameter at breast height (DBH) of the $R$. pseudoacacia plus trees selected from the five stands 


\section{Peculiarities of the R. pseudoacacia seeds harvested from selected trees}

Morphological traits of the seeds were measured and are presented in Table 3. The large size of the seeds shows the trees of Sâmpetru-Almaşului are worth to note, whereas from the five characteristics analyzed, four traits were recorded with superior and significant values compared with the others stands (Table 3 ). Of the five stands, inferior values of the seeds' characteristics were registered only for the Gălpâia trees, in which the length of the seeds showed inferior differences compared to the others stands.

Table 3. Characteristics of the seeds harvested from $R$. pseudoacacia plus trees, depending on the origin (stand)

\begin{tabular}{|l|c|c|c|c|c|}
\hline $\begin{array}{c}\text { Forest } \\
\text { stand }\end{array}$ & $\begin{array}{c}\text { Length } \\
(\mathrm{mm})\end{array}$ & $\begin{array}{c}\text { Width } \\
(\mathrm{mm})\end{array}$ & $\begin{array}{c}\text { Thickness } \\
(\mathrm{mm})\end{array}$ & $\begin{array}{c}\text { Volume } \\
\left(\mathrm{mm}^{3}\right)\end{array}$ & $\begin{array}{c}\text { Weight } \\
(\mathrm{g})\end{array}$ \\
\hline Sâmpetru-Alm. & $5.13^{\mathrm{a}}$ & $2.94^{\mathrm{a}}$ & $1.97^{\mathrm{bc}}$ & $124.5^{\mathrm{a}}$ & $0.058^{\mathrm{a}}$ \\
\hline Voivodeni & $4.91^{\mathrm{b}}$ & $2.79^{\mathrm{d}}$ & $1.96^{\mathrm{c}}$ & $112.5^{\mathrm{c}}$ & $0.056^{\mathrm{c}}$ \\
\hline Trestia & $4.93^{\mathrm{b}}$ & $2.83^{\mathrm{bc}}$ & $2.01^{\mathrm{a}}$ & $117.5^{\mathrm{b}}$ & $0.057^{\mathrm{b}}$ \\
\hline Chendrea & $4.90^{\mathrm{b}}$ & $2.84^{\mathrm{b}}$ & $1.98^{\mathrm{b}}$ & $115.4^{\mathrm{b}}$ & $0.057^{\mathrm{b}}$ \\
\hline Gălpâia & $4.87^{\mathrm{b}}$ & $2.81^{\mathrm{cd}}$ & $1.98^{\mathrm{b}}$ & $113.5^{\mathrm{bc}}$ & $0.056^{\mathrm{c}}$ \\
\hline Mean & 4.95 & 2.84 & 1.98 & 116.6 & 0.057 \\
\hline
\end{tabular}

Different letters between stands denote significant differences (Duncan test, $\mathrm{p}<0.05$ ).

From Table 4, where are presented the correlations between the traits of the $R$. pseudoacacia seeds, it can be noted that except for the relations in which the thickness of the seeds was involved, among all other pairs of the studied traits significantly correlations were registered.

Table 4. Phenotypic correlations between the analysed characteristics of the seeds harvested from the $R$. pseudoacacia plus trees from the five stands

\begin{tabular}{|l|c|c|c|c|}
\hline \multicolumn{1}{|c|}{ Correlated trait } & Width & Thickness & Volume & Weight \\
\hline Length & $0.936^{*}$ & -0.191 & $0.948^{*}$ & $0.913^{*}$ \\
\hline Width & & -0.047 & $0.978^{* *}$ & $0.966^{* *}$ \\
\hline Thickness & & & 0.085 & -0.017 \\
\hline Volume & & & & $0.954^{*}$ \\
\hline
\end{tabular}

$$
\text { r } 5 \%=0.878 ; \text { r } 1 \%=0.959 ; \text { r } 0.1 \%=0.991 \text {. }
$$

Close positive correlations were identified between the following pairs of characters: seed length - seed width; seed length - seed volume; seed length - seed weight. Also, the width of the seeds was correlated with their volume and weight, and the volume of the seeds was significantly correlated with the weight of the seeds.

On the other hand, the percentage of plant emergence in solar and field conditions, as well as the growth of the seedlings obtained from the respective seeds (Table 5), varied considerably depending on the stand (provenance) and growing conditions.

Table 5. Percentage of emergence and growth of seedlings obtained from the seeds of $R$. pseudoacacia trees selected from the five stands, grown in solar and field conditions

\begin{tabular}{|l|c|c|c|c|c|c|}
\hline \multirow{2}{*}{\begin{tabular}{c}
\multirow{2}{*}{$\begin{array}{c}\text { Forest } \\
\text { stand }\end{array}$} \\
\cline { 2 - 7 }
\end{tabular}} & \multicolumn{2}{|c|}{ Seedling emergence (\%) } & \multicolumn{2}{c|}{ Plant height $(\mathrm{cm})$} & \multicolumn{2}{c|}{ Plant thickness $(\mathrm{cm})$} \\
\hline Sâmpetru-Alm. & $73.7^{\mathrm{a}}$ & $41.3^{\mathrm{a}}$ & $5.6^{\mathrm{a}}$ & $3.9^{\mathrm{b}}$ & $0.23^{\mathrm{a}}$ & $0.12^{\mathrm{d}}$ \\
\hline Voivodeni & $68.7^{\mathrm{a}}$ & $33.0^{\mathrm{c}}$ & $4.7^{\mathrm{bc}}$ & $3.8^{\mathrm{b}}$ & $0.16^{\mathrm{b}}$ & $0.18^{\mathrm{bc}}$ \\
\hline Trestia & $70.0^{\mathrm{a}}$ & $35.7^{\mathrm{b}}$ & $4.0^{\mathrm{c}}$ & $3.6^{\mathrm{b}}$ & $0.13^{\mathrm{b}}$ & $0.15^{\mathrm{cd}}$ \\
\hline Chendrea & $52.7^{\mathrm{c}}$ & $37.0^{\mathrm{b}}$ & $3.6^{\mathrm{d}}$ & $4.5^{\mathrm{a}}$ & $0.15^{\mathrm{b}}$ & $0.20^{\mathrm{ab}}$ \\
\hline Gălpâia & $62.3^{\mathrm{b}}$ & $41.0^{\mathrm{ab}}$ & $5.0^{\mathrm{ab}}$ & $4.8^{\mathrm{a}}$ & $0.15^{\mathrm{b}}$ & $0.23^{\mathrm{a}}$ \\
\hline
\end{tabular}

Different letters between stands denote significant differences (Duncan test, $\mathrm{p}<0.05$ ). 
The percentage of $R$. pseudoacacia seedlings obtained from seeds sown into pots in solarium was between $52.7 \%$ at the plus trees from Chendrea and $73.7 \%$ at the plus tees from Sâmpetru-Almaşului. In the field conditions, the same percentage ranged between 33.0\% (Voivodeni) and 41.3\% (Sâmpetru-Almaşului). Also, from the presented data, it can be noticed that between the growth of the seedlings obtained from the seeds of the plus trees there was not a similar behaviour depending on the provenance, for the height and thickness of the young plants, respectively. On the contrary, in some cases, the same provenance was recorded with lower values for the growth of plants in solarium conditions, but with higher values for the growth of plants in field conditions. There was no correlation between the percentage of the emergence of seedlings from the potted seeds in the solarium and those from the field conditions $(r=0.035)$ (Figure 5).

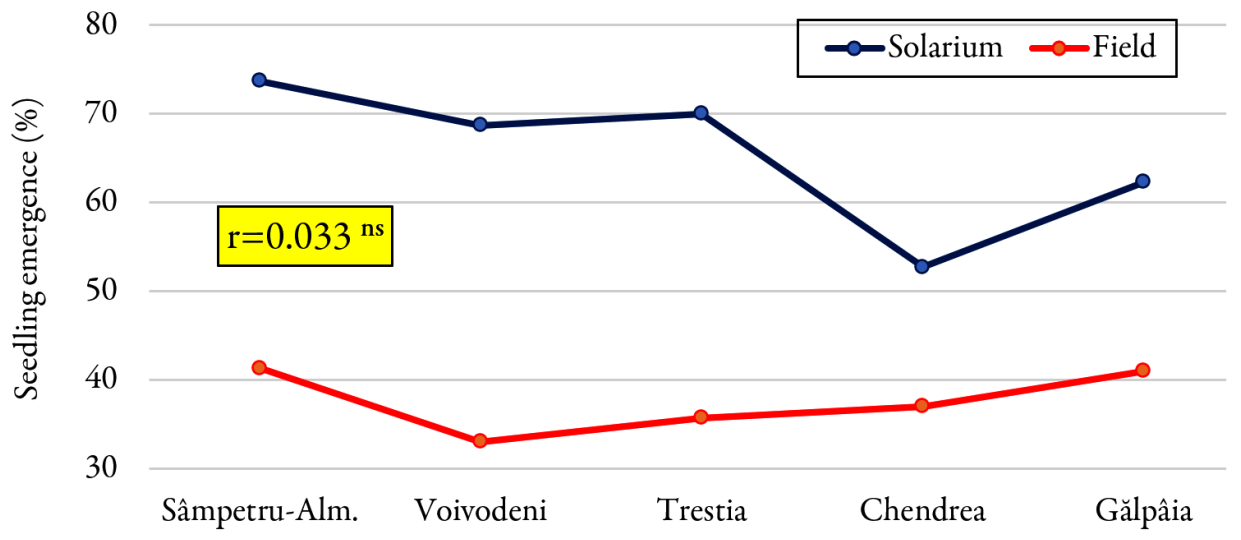

Figure 5. Coefficient of correlation between seedlings' emergence (as a percentage of total sown seeds belonging to plus trees selected in five stands) in two different conditions: grown in the solarium and the field

The obtained results suggest that $R$. pseudoacacia is a species with an inconsistent behaviour for germination and seedlings' emergence, depending on the environmental situation, based on the evolution of the plants obtained in the solarium in regard with field conditions.

By comparing the average values of plant emergence and seedlings' growth one month after sowing (for all five sources), in the two different conditions investigated hereby: solarium and field, were obtained the results presented in Figure 6. Seedlings' emergence was significantly favoured by the conditions in the solarium compared to those in the field. In contrast, after emergence, the height of the plants and the thickness of the stem did not register significant differences in the two test conditions. Consequently, there were no real differences between the two parameters measured one month after sowing the seeds of the selected trees.

\section{Peculiarities of the R. pseudoacacia seedlings obtained from plus trees seeds}

The results of the main characteristics of $R$. pseudoacacia seedlings obtained from seed from the plus trees selected from the five stands, at the end of the first year of vegetation, are presented in Figure 7 . The fastest growth rate was registered in the seedlings coming from the plus trees from Voivodeni stand, while the seedlings descending from the plus trees selected in Sâmpetru-Almaşului presented a small vigour at the end of the first year of life. Seedlings from Chendrea were recorded with the lowest stem height up to the first branch, with significantly significant deviations from the average. Due to the relatively low vigour of the seminal descendants and especially due to the fact that the branching of the stem begins at the lowest height in the experience, the seedlings of Chendrea were considered as the least valuable. 


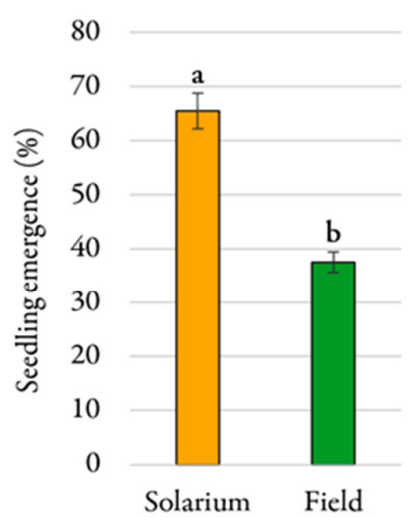

a)

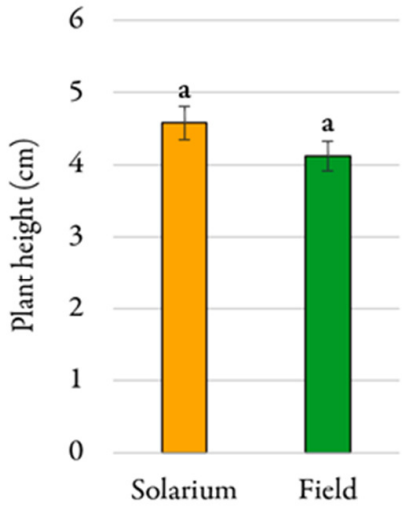

b)

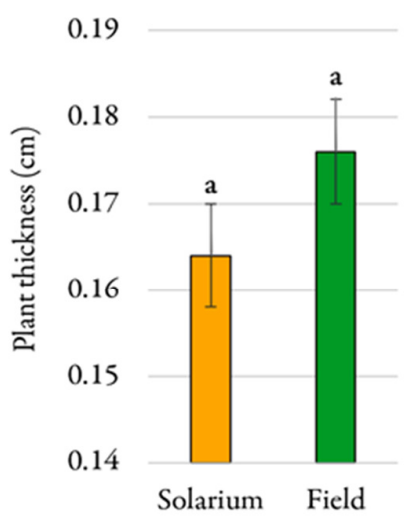

c)

Figure 6. Comparison of the values of seedlings' emergence (a), plant height (b) and plant thickness (c), in two different conditions: solarium and field (as mean \pm SE)

Seedlings were measured one month after sowing the seeds from selected plus trees

T-test for two-sample assuming equal variances, $\alpha=0.05$; $\mathrm{p}$ - value: 0.0001 (seedling emergence); 0.3071 (plant height); 0.6533 (plant thickness)
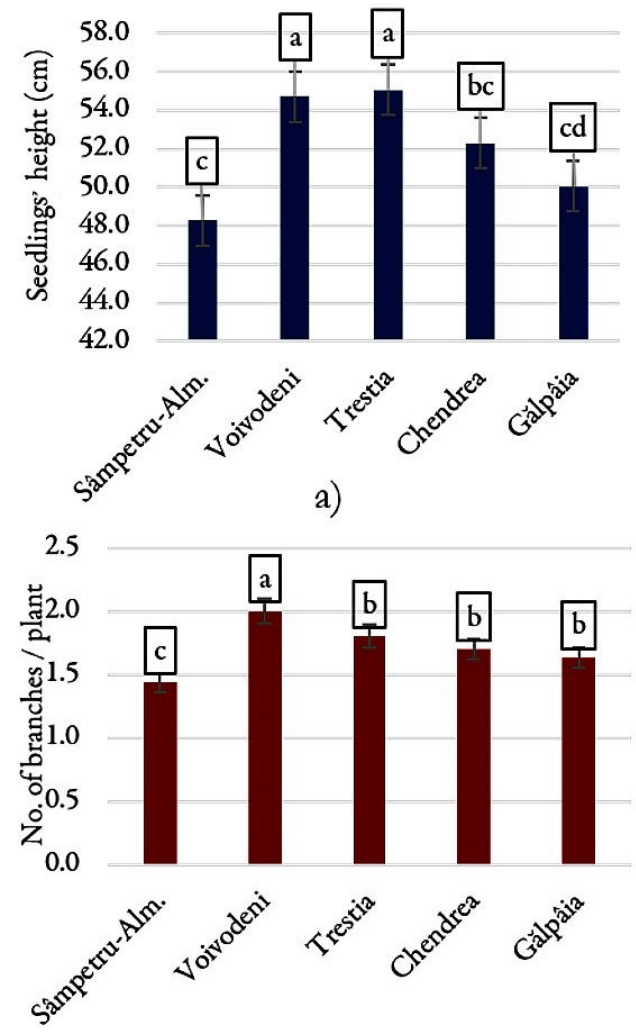

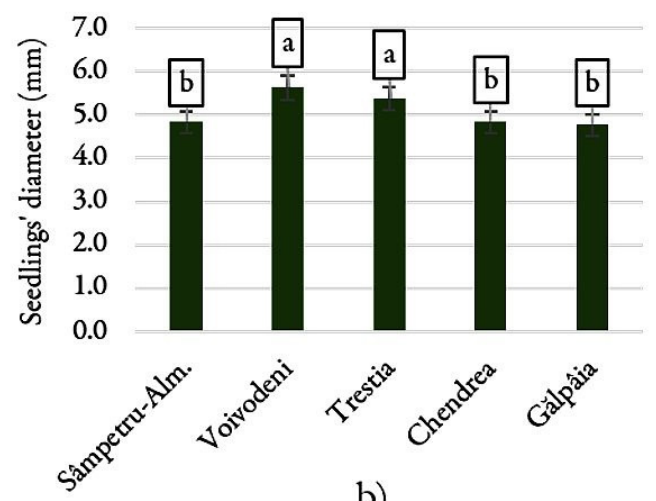

b)

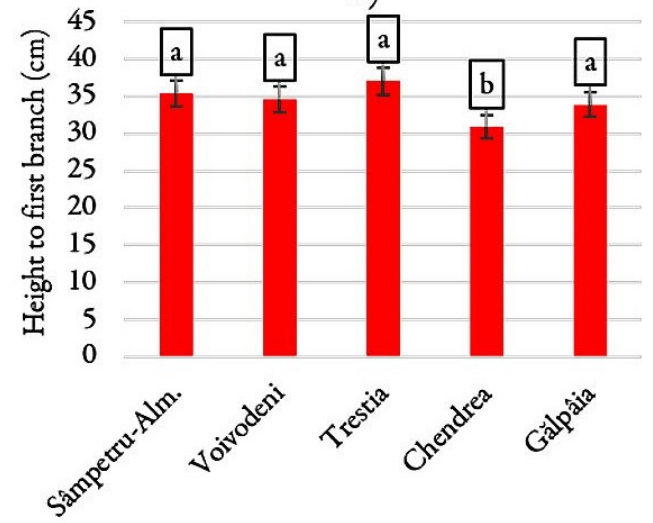

Figure 7. The main characteristics of seedlings at the end of the first year of vegetation, depending on the origin stand: a) Seedlings height (cm); b) Seedlings diameter (mm); c) Number of branches/seedlings; d) Height to the first branch $(\mathrm{cm})$, as mean \pm SE 


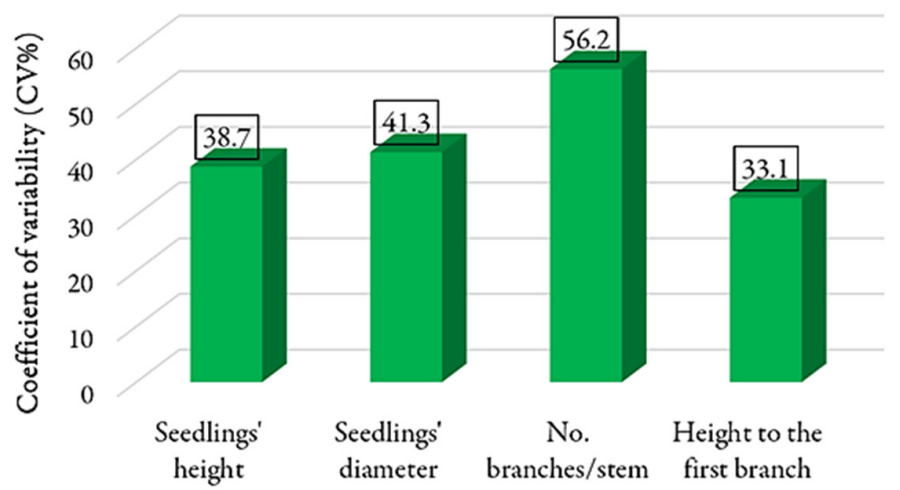

Figure 8. Coefficient of variability (CV\%) for the main growth elements of $R$. pseudoacacia seedlings grown in the field at the end of the vegetation period of the first year of life

The coefficient of variability calculated at the seedlings grown in the field at the end of the vegetation period of the first year of life, on the whole experience, illustrates a very wide variability of all the analyzed characters (Figure 8). The lowest value of CV\% was registered at the stem height up to the first branch $(33.1 \%)$, while the highest value was for the number of branches per stem (56.2\%). Such variability may be useful in specie breeding but is less desirable in the process of producing planting material for afforestation.

Within the provenances from the five stands, positive and close phenotypic correlations were identified between different characteristics of the seedlings: the diameter of the seedlings with the height of the seedlings and with the number of branches per plant; the height of the seedlings with the number of branches per plant. Between the height of the stem up to the first branch and the other elements of growth vigour (seedling height, seedling diameter, number of branches per plant) no statistically assured correlations were determined at the phenotypic level.

The phenotypic correlation coefficients $\left(\mathrm{r}_{\mathrm{p}}\right)$ between the main characteristics of the seedlings resulting from the selected trees on the whole stands highlight that both the height of the seedlings and seedlings' diameter were positively correlated with the number of branches per stem (Table 6). However, there were no significant correlations between the other traits.

Table 6. Phenotypic correlations $\left(\mathrm{r}_{\mathrm{p}}\right)$ between the analysed characteristics of the seedlings resulted from the $R$. pseudoacacia selected trees, computed for the means of all provenances

\begin{tabular}{|l|c|c|c|}
\hline \multicolumn{1}{|c|}{ Correlated trait } & Diameter of seedlings & Number of branches & Height to the first branch \\
\hline The height of the seedlings & 0.838 & $0.912^{*}$ & 0.195 \\
\hline Diameter of seedlings & & $0.862^{*}$ & 0.468 \\
\hline Number of branches & & & 0.056 \\
\hline
\end{tabular}

r $5 \%=0.878 ;$ r $1 \%=0.959 ;$ r $0.1 \%=0.991$.

In contrast, when the genotypic correlations were calculated between seedlings' traits (in half sib families obtained by open pollination of plus tree, per 100 seedlings chosen at random), all correlations were positive and significant (Table 7). Also, among all the growth elements analysed (seedling height, seedling diameter, number of branches per stem, stem height up to the first branch), the genotypic correlation coefficients had very high values, at the significance level of alpha 0.001 . 
Table 7. Genotypic correlations between the analysed characteristics of the seedlings belonging to the selected $R$. pseudoacacia trees open pollinated, from five stands (there were analysed 100 randomised seedlings belongings to the half sib families, respectively plus trees selected from each stand)

\begin{tabular}{|c|l|c|c|c|}
\hline $\begin{array}{c}\text { Forest } \\
\text { stand }\end{array}$ & \multicolumn{1}{|c|}{$\begin{array}{c}\text { Correlated } \\
\text { trait }\end{array}$} & $\begin{array}{c}\text { Diameter of } \\
\text { seedlings }\end{array}$ & $\begin{array}{c}\text { Number of } \\
\text { branches }\end{array}$ & $\begin{array}{c}\text { Height to the first } \\
\text { branch }\end{array}$ \\
\hline \multirow{3}{*}{$\begin{array}{c}\text { Sâmpetru- } \\
\text { Alm. }\end{array}$} & The height of the seedlings & 0.892 & 0.882 & 0.930 \\
\cline { 2 - 5 } & Diameter of seedlings & - & 0.864 & 0.827 \\
\cline { 2 - 5 } Voivodeni & Number of branches & - & - & 0.728 \\
\hline \multirow{4}{*}{ Trestia } & The height of the seedlings & 0.946 & 0.916 & 0.945 \\
\cline { 2 - 5 } & Diameter of seedlings & - & 0.931 & 0.880 \\
\cline { 2 - 5 } & Number of branches & - & - & 0.842 \\
\hline \multirow{4}{*}{ Chendrea } & The height of the seedlings & 0.952 & 0.939 & 0.928 \\
\cline { 2 - 5 } & Diameter of seedlings & - & 0.943 & 0.887 \\
\cline { 2 - 5 } & Number of branches & - & - & 0.838 \\
\cline { 2 - 5 } & The height of the seedlings & 0.917 & 0.816 & 0.869 \\
\cline { 2 - 5 } & Diameter of seedlings & - & - & 0.815 \\
\hline \multirow{3}{*}{ Gălpâia } & Number of branches & - & 0.944 & 0.632 \\
\cline { 2 - 5 } & Diameter of seedlings & - & 0.950 & 0.891 \\
\cline { 2 - 5 } & Number of branches & - & - & 0.850 \\
\hline
\end{tabular}

The heritability coefficients in broad sense calculated for half-sib families varied between 0.216 and 0.811 (Figure 9). The highest value, suggesting a strong influence of the genotype in the hereditary transmission of the trait, was recorded for seedlings' diameter. It seems that seedlings' height and stem height to the first branch are traits in which the largest influence of the genetic variance is of additive nature. For such traits, mass selection can offer satisfactory genetic gains.

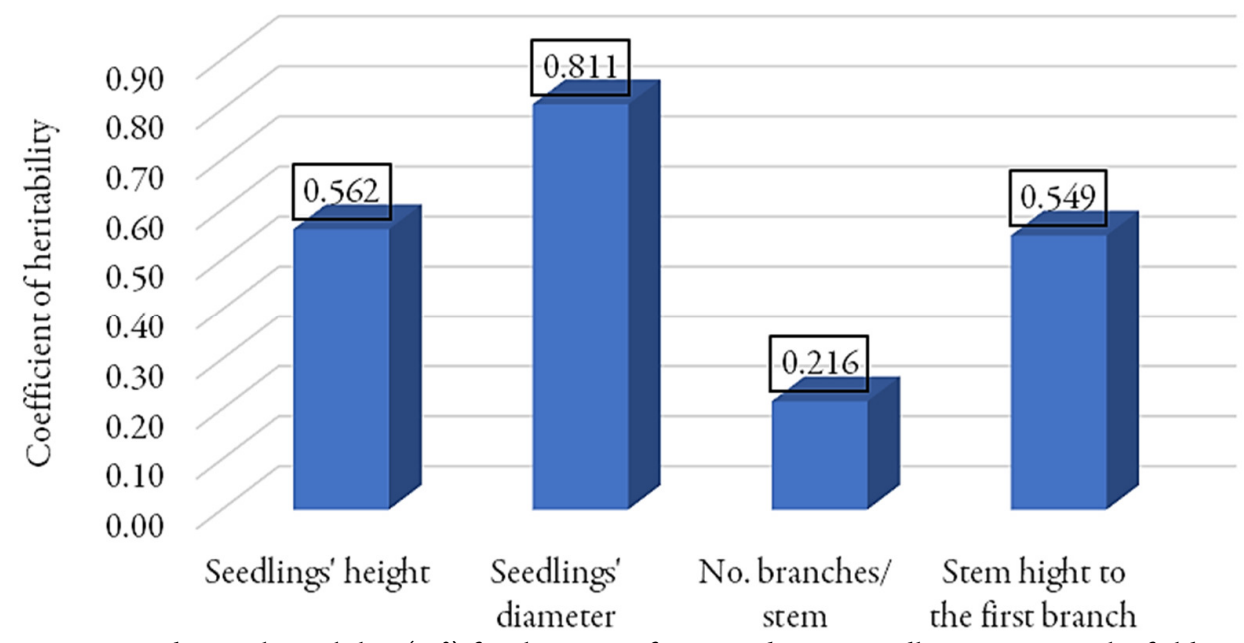

Figure 9. Broad-sense heritability $\left(\mathrm{H}^{2}\right)$ for the traits of $R$. pseudoacacia seedlings grown in the field, at the end of the first year of vegetation

The calculation was performed by partitioning the variances based on the half-sib families

The lowest contribution of the genotype to the manifestation of the analyzed characters was registered for the number of branches on the stem. This character is, therefore, more strongly influenced by the environmental conditions, and less heritable. Consequently, the results suggest how the selection can be applied to $R$. pseudoacacia for valuable biological plant material. 


\section{Discussion}

\section{Plus tree}

The descendants of plus-trees selected for yield traits tend to grow faster, especially at young stages. It is argued that this observed trend may be due, at least partially, as a response to selection (Rédei et al., 2008; Dyderski and Jagodziński, 2019). The selection of quality plus trees is an essential and basic step to all tree breeding and conservation strategies (Kant et al., 2006). The reported values showed that genetic gains of up to $15 \%$ increase in height and diameter, and up to $35 \%$ in volume per unit area, can easily be obtained by selecting plus-tree (Cornelius, 1994). Following the selection from the five stands analyzed of plus trees that had favourable characteristics, there were identified notable differences for main traits of the trees, among stands.

Plus trees are usually chosen in valuable natural stands, which often represent true gene centres of wood species (Savolainen et al., 2007). The theory underlying plus tree selection is that the favourable deviation of the plus trees from the population means is due at least in part to genetic effects, rather than ecological or random effects (Kim et al., 2020). In the present study, the plus trees with the highest vigour were those from the Voivodeni stand, with superior values for important growth characteristics: the height of the trees, the diameter of the trunk, the basal area, or the area of the cross-section of the trunk and self-pruning trunk length. Trees from this stand had the advantage of a longer self-pruning trunk length compared to other stands. The plus trees with the lowest vigour were reordered in Gălpâia, with inferior values compared to the other stands for the trunk diameter, the surface of the trunk cross-section, the large and the small diameter of the crown.

It is known that in the case of black locust wood is different between juvenile and adult stages (Dünisch et al., 2007; Koch and Dünisch, 2008; Dünisch et al., 2010; Latorraca et al., 2011; Carl et al., 2019). Because the stands and consequently plus trees, were of different ages, it was investigated and correlations were further made in order to estimate how age influences important characteristics of trees' vigour and wood quality. It is interesting to note that these correlations were not statistically assured as it was expected.

\section{Peculiarities of the seeds harvested from selected plus trees}

Seeds of $R$. pseudoacacia are known to have a hard coat which is impermeable to water (Singh et al., 1991). Such types of seeds frequently exhibit physical dormancy, whereas exposure to high temperature for example results in high germination percentages (Baskin et al., 2000). Black locust, in fact, produces both dormant and non-dormant seeds, the latter of which can germinate without scarification (Masaka and Yamada 2009; Karaki et al., 2012).

After analyzing the seeds harvested from $R$. pseudoacacia plus trees, it was noticed that between provenances there were differences for the seed's characteristics. On the whole experience, were identified close positive correlations between some characteristics of the seeds.

Larger seeds were those obtained from the trees of Sâmpetru-Almaşului, for which characteristics as length $(\mathrm{mm})$, width $(\mathrm{mm})$, volume $\left(\mathrm{mm}^{3}\right)$ and weight $(\mathrm{g})$ recorded superior and significant values compared to the others stands, while the inferior values of the seeds' elements were registered for the Gălpâia trees. There were identified close positive correlations between some characteristics such as: seed length - seed width; seed length - their volume; seed length - their weight. Even though literature in the field is scarce for black locust, other species of Fabaceae were noted to have correlations among seeds' traits, that can be used for selecting valuable genitors (Escribano et al., 1997; Dalla Corte et al., 2010).

Seeds represent an important part in the development, generation viability and dispersal of plants. The germination features of $R$. pseudoacacia seeds may differ significantly among seed sources (trees) (Masaka and Yamada, 2009). From the presented data obtained in the current investigation, it can be noticed that the growth of the seedlings obtained from seeds of the plus trees had different behaviour depending on their provenance, for the height and thickness of the young plants. On the contrary, in some cases, the same provenance seedlings were recorded with lower values for the growth of plants in solarium conditions, but with 
higher values for the growth of plants in field conditions. The obtained results suggest that $R$. pseudoacacia is a species with an inconsistent behaviour for germination and seedlings' emergence, depending on the environmental conditions, seen hereby within the evolution of the plants grown in the solarium or outside in the field.

By comparing the average values of plant emergence and seedlings' growth one month after sowing (on all five sources), in the two different conditions, solarium and field, it was noticed that seedlings' emergence was significantly favoured by the conditions in the solarium compared to those in the field. Such a result can be explained by the proper conditions for germination, that can be controlled more easily in the solarium, compared with the field situation (Porter, 1935; Pedrol et al., 2018), even though these advantages can change in time (Dyderski and Jagodziński, 2019).

Storage period depending on the longevity of the species, seed pre-treatment methods and seed size may affect germination. Larger seeds have led to a higher germination rate because larger seeds contain more food reserves to support germination (Long et al., 2015). The characteristic of the maternal genitor can also affect the behaviour of the seeds. Moreover, the provenance (ecotypes) and the harvest period must be taken into account (Petrie et al., 2016; Kheloufi et al., 2018).

\section{Peculiarities of seedlings obtained from plus trees}

The results regarding the seedlings obtained from $R$. pseudoacacia plus trees have shown that there were marked differences between black locust origins for the main elements of plants' growth and vigour, which fully justified selection, in order to identify the best stand (origin) with the final aim to obtain a better biological material. There are many selection methods, but is with to pay attention to find the best method and selection criteria for the target species (Zobel and Talbert, 1984; Kim et al., 2020), so that for the hereby investigation was considered vigour aspects specific to a fast-growing species, corroborated with the uses of black locust trees.

The fastest growth rate was registered in the seedlings coming from the plus trees from Voivodeni stand, while a small vigour at the end of the first year of vegetation was noted within the seedlings descending from the plus trees selected in Sâmpetru-Almaşului. Due to the relatively low vigour of the seminal descendants and especially due to the fact that the branching of the stem begins at the lowest height in the experience, the seedlings of Chendrea was considered as the least valuable.

Within the provenances studied in the current experience, positive and close phenotypic correlations were identified between different characteristics of the seedlings. The phenotypic correlation coefficients $\left(r_{p}\right)$ between the main characteristics of the seedlings resulting from the selected trees on the whole stands highlight that both the height of the seedlings and seedlings' diameter were positively correlated with the number of branches per stem. However, there were no significant correlations between the other traits studied. In contrast, when the genotypic correlations were calculated between seedlings' traits, all the correlations were positive and significant. Thus, the selection of the plus trees from which seeds to be collected is worth making, in order to obtain good quality plant material.

The heritability coefficients in broad sense had relatively high values. The highest value, suggesting a major influence of the genotype in the hereditary transmission of the character (Howe et al., 2003; Rodríguez, 2013), was recorded for seedlings' diameter. It seems that seedlings' height and stem height to the first branch are traits in which the largest part of the genetic variance is of the additive nature. For such traits, mass selection can offer satisfactory genetic gains.

The identified correlations illustrate the fact that in the biological material represented by the seminal descendants of $R$. pseudoacacia there were only positive relationships between the traits of seedlings' growth, some of them being statistically assured, with different levels of significance. The identification of the respective correlations (especially those at genotypic level) allows obtaining useful information for selection. For example, by indirect selection, is possible to select valuable seedlings in a young phase, on the basis of a less important trait, but easy to analyse, and which is known as closely correlated with a trait of interest. Such a correlation can be of use for perennial species that are of interest and for traits more difficult to analyse. It is necessary though 
to further investigate these correlations and to better understand the relationships that can occur for such features.

\section{Conclusions}

Taking into account the close correlations at the genotypic level, it can be concluded that indirect selection can be applied within black locust seedlings, as it is considered particularly effective for the selection of valuable specimens from the nursery, to be used later for afforestation or other purposes. The information obtained calculating the genetic parameters such as: coefficients of variability, phenotypic and genotypic correlation, heritability can be very useful for the forestry practice, in order to direct the trees growth and wood production, but also for breeding work, where traits' close correlated can be used as selection indices. For the breeding of $R$. pseudoacacia, the current data can provide valuable information for forestry practice and science, being in the same time a starting point for initiating new selection and development works on the species.

\section{Authors' Contributions}

Conceptualization: AFS, LH, FI, RES; Data curation: AMR, DC, AMT; Formal analysis: AFS, RES; Funding acquisition: AMR, DC; Investigation: AMR, IMM, AMT, CD; Methodology: IMM, AMT, LH, RES; Supervision: AFS, LH, RES; Writing - original draft: IMM, CD; Writing - review and editing: IMM, AMT, CD, FI.

All authors read and approved the final manuscript.

\section{Acknowledgements}

This research received no specific grant from any funding agency in the public, commercial, or not-forprofit sectors. The support of the UK Forest Research in sharing the necessary information on their black locust integration into UK forests is much appreciated.

\section{Conflict of Interests}

The authors declare that there are no conflicts of interest related to this article.

\section{References}

An S, Mentler A, Mayer H, Blum WE (2010). Soil aggregation, aggregate stability, organic carbon and nitrogen in different soil aggregate fractions under forest and shrub vegetation on the Loess Plateau, China. Catena 81(3):226-233. https://doi.org/10.1016/j.catena.2010.04.002

Balat M (2010). Bio-oil production from pyrolysis of black locust (Robinia pseudoacacia) wood. Energy Exploration and Exploitation 28:173-186. https://doi.org/10.1260/0144-5987.28.3.173

Baskin CC (2000). Breaking physical dormancy in seeds-focussing on the lens. The New Phytologist 158:229-232.

https://doi.org/10.1046/j.1469-8137.2003.00751.x

Bonner FT, Karrfalt RP (2008). The woody plant seed manual. USDA Agricultural Handbook 727:1-1223.

Boring LR, Swank WT (1984). The role of black locust (Robinia pseudoacacia) in forest succession. The Journal of Ecology 1:749-66.

Bos I, Caligari P (2007). Selection methods in plant breeding. Springer Science \& Business Media. 
Bouteiller XP, Porté AJ, Mariette S, Monty A (2017). Using automated sanding to homogeneously break seed dormancy in black locust (Robinia pseudoacacia L., Fabaceae). Seed Science Research 27(3):243. https://doi.org/10.1017/S0960258517000150

Carl C, Lehmann JR, Landgraf D, Pretzsch H (2019). Robinia pseudoacacia L. in short rotation coppice: Seed and stump shoot reproduction as well as UAS-based spreading analysis. Forests 10(3):235. https://doi.org/10.3390/f10030235

Cierjacks A, Kowarik I, Joshi J, Hempel S, Ristow M, von der Lippe M, Weber E (2013). Biological flora of the British Isles: Robinia pseudoacacia. Journal of Ecology 101(6):1623-1640. https://doi.org/10.1111/1365-2745.12162

Ciuvăț AL, Abrudan IV, Blujdea V, Dutca I, Nuță IS, Edu E (2013). Biomass equations and carbon content of young black locust (Robinia pseudoacacia L.) trees from plantations and coppices on sandy soils in south-western Romanian Plain. Notulae Botanicae Horti Agrobotanici Cluj-Napoca 41(2):590-592. https://doi.org/10.15835/nbha4129355

Ciuvăț AL, Abrudan IV, Blujdea V, Marcu C, Dinu C, Enescu C, Nuţă IS (2013). Distribution and peculiarities of black locust in Romania. Revista de Silvicultură şi Cinegetică 32:76-85. https://www.cabi.org/ISC/FullTextPDF/2014/20143263765.pdf

Cornelius J (1994). The effectiveness of plus-tree selection for yield. Forest Ecology and Management 67(1-3):23-34.

Costea A, Lazarescu C, Birlanescu E, Ivanschi T, Armașescu S, Trantescu G, Latiş L, Pirvu E (1969). Recommendations on black locust culture. ICSPS, București pp 38.

Dalby R (2004). A honey of a tree: black locust. American Bee Journal 144:382-384.

Dalla Corte A, Moda-Cirino V, Arias CA, Toledo JF, Destro D (2010). Genetic analysis of seed morphological traits and its correlations with grain yield in common bean. Brazilian Archives of Biology and Technology 53(1):27-34. https://doi.org/10.1590/S1516-89132010000100004

Damian I (1978). Afforestations. Editura Didactică și Pedagogică. București pp 374.

DeGomez T, Wagner MR (2001). Culture and use of black locust. Hort Technology 11(2):279-288.

Drăcea M (2008). Contribuții la cunoaşterea salcâmului în România cu privire specială asupra culturii sale pe solurile nisipoase din Oltenia. Cenuşă R, Râşcă M: traducere din limba germană. Editura Silvică pp 93.

Dünisch O, Koch G, Dreiner K (2007). Verunsicherung uber die Eigenschaften von Robinienholz. Holz Zentralblatt 39:1061-1062.

Dünisch O, Richter HG, Koch G (2010). Wood properties of juvenile and mature heartwood in Robinia pseudoacacia L. Wood Science and Technology 44:301-313. https://doi.org/10.1007/s00226-009-0275-0

Dyderski MK, Jagodziński AM (2019). Seedling survival of Prunus serotina Ehrh., Quercus rubra L. and Robinia pseudoacacia L. in temperate forests of Western Poland. Forest Ecology and Management 450:117498. https://doi.org/10.1016/j.foreco.2019.117498

Enescu M, Dănescu A (2013). Black locust (Robinia pseudoacacia L.) - an invasive neophyte in the conventional land reclamation flora in Romania. Bulletin of the Transilvania University of Brasov, Series II-Forestry Wood Industry Agricultural Food Engineering 6(55):2.

Ernyey J (1927). Die Wanderwege der Robinie und ihre Ansiedlung in Ungarn. Magyar Botanikai Lapok 25:161-191.

Escribano M, Santalla M, de Ron A (1997). Genetic diversity in pod and seed quality traits of common bean populations from northwestern Spain. Euphytica 93:71-81. https://doi.org/10.1023/A:1002908224793

Farrar JL (1995). Trees of the Northern United States and Canada. Blackwell Publishing: Ames, IA, USA pp 502.

Gillespie AR, Pope PE (1990). Rhizosphere acidification increases phosphorus recovery of black locust: II. Model predictions and measured recovery. Soil Science Society of America Journal 54:538-541.

Giurgiu V (2005). Marin Drăcea - Opere alese. Editura Ceres, Bucureşti pp 400.

González-García S, Gasol CM, Moreira MT, Gabarrell X, i Pons JR, Feijoo G (2011). Environmental assessment of black locust (Robinia pseudoacacia L.) based ethanol as potential transport fuel. The International Journal of Life Cycle Assessment 16:465-477. https://doi.org/10.1007/s11367-011-0272-Z

Grünewald H, Böhm C, Quinkenstein A, Grundmann P, Eberts J, von Wühlisch G (2009). Robinia pseudoacacia L.: a lesser-known tree species for biomass production. BioEnergy Research 2:123-133. https://doi.org/10.1007/s12155-009-9038-X

Guo XP, Zhu JZ, Yu XX, Luo J (2005). Ways to improve low-benefit black locust forests in Loess Plateau. Forestry Studies in China 7(2):57-62.

Haralamb A (1967). Culture of tree species (in Romanian). Editura Agro-Silvică, Bucharest, Romania. 
Howe GT, Aitken SN, Neale DB, Jermstad KD, Wheeler NC, Chen TH (2003). From genotype to phenotype: unravelling the complexities of cold adaptation in forest trees. Canadian Journal of Botany 81(12):1247-1266. https://doi.org/10.1139/b03-141

Huntley JC (1990). Robinia pseudoacacia L. In: Silvics of North America, Vol 2. Hardwoods. Burns RM, Honkala BH (Eds). USDA Foreign Agricultural Service Handbook 654: Washington, DC, USA pp 755-761.

Ivanschi T, Costea A, Bîrlănescu E, Mărcoiu A, Nonuțe I (1969). Cercetări privind stabilirea stațiunilor apte pentru cultura salcâmului. Cercetări privind cultura salcâmului. Editura Agrosilvică Bucureşti pp 11-55.

Jayaraman K (2000). A statistical manual for forestry research. Food and Agriculture Organization of the United Nations. Forestry Research Support Programme for Asia and the Pacific, FORSPA. Kerala Forest Research Institute. Regional Office for Asia and the Pacific, Bangkok. http://www.fao.org/3/X6831E/X6831E00.htm\#TOC

Kim IS, Lee KM, Shim D, Kim JJ, Kang HI (2020). Plus tree selection of Quercus salicina Blume and Q. glauca Thunb. and its implications in evergreen oaks breeding in Korea. Forests 11(7):735.

Kant A, Dutt V, Sharma DR (2006). Genetic variability in phenotypic characters of Pinus gerardiana. Indian Forester 132:681-690.

Karaki T, Watanabe Y, Kondo T, Koike T (2012). Strophiole of seeds of the black locust acts as a water gap. Plant Species Biology 27:226-232. https://doi.org/10.1111/j.1442-1984.2011.00343.x

Keresztesi B (1980). The black locust. Unasylva 32(127):23-33.

Keresztesi B (1988). The black locust. Akademiai Kiado, Budapest pp 196.

Kheloufi A, Mansouri L, Aziz N, Sahnoune M, Boukemiche S, Ababsa B (2018). Breaking seed coat dormancy of six tree species. Reforesta (5):4-14. https://dx.doi.org/10.21750/REFOR.5.02.48

Koch G, Dünisch O (2008). Juvenile wood in Robinie-Qualität von Robinienholz (Robinia pseudoacacia L.) und Folgerungen für Holzbearbeitung und Produktqualität. Abschlussbericht für das DGfH/AIFForschungsvorhaben, Fraunhofer IRB Verlag: Stuttgart, Germany.

Kolbek J, Vítková M, Vetvicka V (2004). From history of Central European Robinia growths and its communities. Zprávy České Botanické Společnosti 39:287-298.

Kowarik I (1992). Einführung und Ausbreitung nichteinheimischer Gehölzarten in Berlin und Brandenburg und ihre Folgen für Flora und Vegetation: ein Modell für die Freisetzung gentechnisch veränderter Organismen. Botanischer Verein von Berlin und Brandenburg.

Latorraca JVF, Dünisch O, Koch G (2011). Chemical composition and natural durability of juvenile and mature heartwood of Robinia pseudoacacia L. Anais da Academia Brasileira de Ciências: 83:1059-1068. https://doi.org/10.1590/S0001-37652011005000016.

Little EL (1971). Atlas of United States Trees; Conifers and Important Hardwoods, US Department of Agriculture, Forest Service: Washington, DC, USA.

Liu NY, Khatamian H, Freta TA (1981). Seed coat structure of three woody legume species after chemical and physical treatments to increase seed germination. Journal of the American Society for Horticultural Science 106(5):691694.

Long RL, Gorecki MJ, Renton M, Scott JK, Colville L, Goggin DE, ... Finch-Savage WE (2015). The ecophysiology of seed persistence: a mechanistic view of the journey to germination or demise. Biological Reviews 90(1):31-59. https://doi.org/10.1111/brv.12095

Lukasiewicz M, Kowalski S, Makarewicz M (2015). Antimicrobial an antioxidant activity of selected Polish herbhoneys. LWT-Food Science and Technology 64(2):547-553. DOI: 10.1016/j.lwt.2015.06.029

Masaka K, Yamada K (2009). Variation in germination character of Robinia pseudoacacia L. (Leguminosae) seeds at individual tree level. Journal of Forest Research 14(3):167. https://doi.org/10.1007/s10310-009-0117-9

Min-Sheng Y, Hertel H, Schneck V (2004). Allozyme variability of provenance populations of Robinia pseudoacacia from middle Europe. Acta Genetica Sinica 31(12):1439-1447.

Negulescu E, Savulescu A (1957). Dendrology. Editura Agro-Silvica de Stat, București.

Nețoiu C (2012). Asistență tehnică privind conservarea şi extinderea în cultură a genotipurilor valoroase de salcâm var. Oltenica (Robinia pseudoacacia var. Oltenica). Referat ICAS.

Nicolescu VN, Hernea C, Bakti B, Keserü Z, Antal B, Rédei K (2018). Black locust (Robinia pseudoacacia L.) as a multipurpose tree species in Hungary and Romania: a review. Journal of Forestry Research 29(6):1449-1463. https://doi.org/10.1007/s11676-018-0626-5 
Nicolescu VN, Rédei K, Mason WL, Vor T, Pöetzelsberger E, Bastien JC, ... Andrašev S (2020). Ecology, growth and management of black locust (Robinia pseudoacacia L.), a non-native species integrated into European forests. Journal of Forestry Research 31:1081-1101. https://doi.org/10.1007/s11676-020-01116-8

Olesniewicz KS, Thomas RB (1999). Effects of mycorrhizal colonization on biomass production and nitrogen fixation of black locust (Robinia pseudoacacia) seedlings grown under elevated atmospheric carbon dioxide. The New Phytologist 142:133-140. https://doi.org/10.1046/j.1469-8137.1999.00372.x

Pedrol N, Puig CG, López-Nogueira A, Pardo-Muras M, González L, Souza-Alonso P (2018). Optimal and synchronized germination of Robinia pseudoacacia, Acacia dealbata and other woody Fabaceae using a handheld rotary tool: concomitant reduction of physical and physiological seed dormancy. Journal of Forestry Research 29(2):283-90. https://doi.org/10.1007/s11676-017-0445-0

Petrie MD, Wildeman AM, Bradford JB, Hubbard RM, Lauenroth WK (2016). A review of precipitation and temperature control on seedling emergence and establishment for ponderosa and lodgepole pine forest regeneration. Forest Ecology and Management 361:328-338. https://doi.org/10.1016/j.foreco.2015.11.028

Porter RH (1935). Germination of seeds of black locust (Robinia pseudacacia L.). In: Proceedings of the Association of Official Seed Analysts of North America 1935 January 1, Volume 27 pp 63-65.

Qiu L, Zhang X, Cheng J, Yin X (2010). Effects of black locust (Robinia pseudoacacia) on soil properties in the loessial gully region of the Loess Plateau, China. Plant and Soil 332(1-2):207-217. https://doi.org/10.1007/s11104010-0286-5

Quinkenstein A, Jochheim H (2016). Assessing the carbon sequestration potential of poplar and black locust short rotation coppices on mine reclamation sites in Eastern Germany-Model development and application. Journal of Environmental Management 16:53-66. https://doi.org/10.1016/j.jenvman.2015.11.044

Rédei K, Csiha I, Keseru Z, Gál J (2012). Influence of regeneration method on the yield and stem quality of Black locust (Robinia pseudoacacia L.) stands: a case study. Acta Silvatica et Lignaria Hungarica 8:103-112.

Redei K, Osvath-Bujtas Z, Veperdi I (2008). Black locust (Robinia pseudoacacia L.) improvement in Hungary: a review. Acta Silvatica and Lignaria Hungarica 4:127-132.

Rice SK, Westerman B, Federici R (2004). Impacts of the exotic, nitrogen-fixing black locust (Robinia pseudoacacia) on nitrogen-cycling in a pine-oak ecosystem. Plant Ecology 174:97-107. https://doi.org/10.1023/B:VEGE.0000046049.21900.5a

Rodríguez RL (2013). Causes of variation in genotypex environment interaction. Evolutionary Ecology Research 15(6):733-746.

Rubțov S (1961). Woody species in nursery. Editura Agro-Silvică.

Savolainen O, Pyhäjärvi T, Knürr T (2007). Gene flow and local adaptation in trees. Annual Review of Ecology, Evolution and Systematics 38:595-619. https://doi.org/10.1146/annurev.ecolsys.38.091206.095646

Singh DP, Hooda MS, Bonner FT (1991). An evaluation of scarification methods for seeds of two leguminous trees. New Forest 5:139-145.

Șofletea N, Curtu L (2007). Dendrologie. Editura Universității Transilvania pp 540.

Stănescu V (1979). Dendrologie. Editura Didactica și Pedagogica, București pp 470.

Tateno R, Tokuchi N, Yamanaka N, Du S, Otsuki K, Shimamura T,... Hou Q (2007). Comparison of litterfall production and leaf litter decomposition between an exotic black locust plantation and an indigenous oak forest near Yanan on the Loess Plateau, China. Forest Ecology and Management 241(1):84-90. https://doi.org/10.1016/j.foreco.2006.12.026

Usberti R, Martines L (2007). Sulfuric acid scarification effects on Brachiaria brizantha, B. humidicola and Panicum maximum seed dormancy release. Revista Brasileira de Sementes 29(2):143-147. https://doi.org/10.1590/S0101-31222007000200020

Ussiri DAN, Lal R, Jacinthe PA (2006). Soil properties and carbon sequestration of afforested pastures in reclaimed mine soils of Ohio. Soil Science Society of America Journal 70(5):1797-1806.

https://doi.org/10.2136/sssaj2005.0352

Vítková M, Müllerová J, Sádlo J, Pergl J, Pyšek P (2017). Black locust (Robinia pseudoacacia) beloved and despised: A story of an invasive tree in Central Europe. Forest Ecology and Management 384:287-302. https://doi.org/10.1016/j.foreco.2016.10.057

Wang B, Liu G, Xue S (2012). Effect of black locust (Robinia pseudoacacia) on soil chemical and microbiological properties in the eroded hilly area of China's Loess Plateau. Environmental Earth Sciences 65(3):597-607. https://doi.org/10.1007/s12665-011-1107-8 
Xu Y, Wang T, Li H, Ren C, Chen J, Yang G, ... Wang X (2019). Variations of soil nitrogen-fixing microorganism communities and nitrogen fractions in a Robinia pseudoacacia chronosequence on the Loess Plateau of China. Catena 1(174):316-323. https://doi.org/10.1016/j.catena.2018.11.009

Zhang H, Liu Z, Chen H, Tang M (2016). Symbiosis of arbuscular mycorrhizal fungi and Robinia pseudoacacia L. improves root tensile strength and soil aggregate stability. PloS One 11(4):e0153378. https://doi.org/10.1371/journal.pone.0153378

Zobel B, Talbert J (1984). Applied forest tree improvement. John Wiley \& Sons: New York, USA.

OPEN ACCESS

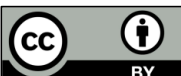

The journal offers free, immediate, and unrestricted access to peer-reviewed research and scholarly work. Users are allowed to read, download, copy, distribute, print, search, or link to the full texts of the articles, or use them for any other lawful purpose, without asking prior permission from the publisher or the author.

License - Articles published in Notulae Scientia Biologicae are Open-Access, distributed under the terms and conditions of the Creative Commons Attribution (CC BY 4.0) License.

(c) Articles by the authors; SHST, Cluj-Napoca, Romania. The journal allows the author(s) to hold the copyright/to retain publishing rights without restriction. 